\title{
PERBANDINGAN KEBIJAKAN PAJAK PENGHASILAN ATAS UKM DI INDONESIA DENGAN NEGARA-NEGARA ANGGOTA OECD
}

\author{
Elsie Sylviana Kasim ${ }^{1}$ \\ Thesa Adi Purwanto ${ }^{2}$ \\ 1,2 Laboratorium Perpajakan, Program Vokasi UI, elsiekasim@yahoo.com, tsaaje@yahoo.com
}

Diterima : 12 Februari 2014

Layak Terbit : 1 Juli 2014

\begin{abstract}
Abstrak
Pemerintah menerapkan Peraturan Pemerintah Nomor 46 Tahun 2013 tentang Pajak Penghasilan atas Penghasilan dari Usaha yang Diterima atau Diperoleh Wajib Pajak yang Memiliki Peredaran Bruto Tertentu dengan tujuan untuk meningkatkan kepatuhan wajib pajak. Bagi Usaha Kecil dan Menengah, penerapan peraturan ini diharapkan dapat memudahkan wajib pajak dalam hal pelaporan pajaknya. Penelitian ini akan menganalisis penerapan kebijakan pengenaan pajak penghasilan final sebesar $1 \%$ dari omset pengusaha Usaha Kecil dan Menengah. Pertimbangan apa saja yang mendasari untuk menerapkan aturan khusus atas Pajak Penghasilan Usaha Kecil dan Menengah, penyederhanaan aturan dan prosedur yang diterapkan dan perbandingan berbagai ketentuan dari beberapa negara yang telah disurvei. Pembahasan akan dilakukan terhadap penerapan kebijakan perpajakan kepada Usaha Kecil dan Menengah yang dilakukan oleh negara-negara Organization for the Cooperation and Economic Development (OECD) yang telah disurvei. Kebijakan perpajakan atas Usaha Kecil dan Menengah yang akan dibandingkan antara lain: pengecualian pajak penghasilan kepada perusahaan dengan omset di bawah ambang batas usaha kecil; penggantian bentuk penghitungan pajak menjadi presumptive tax; penggunaan sistem akuntansi cash basis dan prosedur akuntansi yang telah disederhanakan lainnya.
\end{abstract}

Kata Kunci: Pajak Penghasilan, UKM, OECD.

\begin{abstract}
Government implement Government Regulation Number 46 Year 2013 regarding Income Tax on Income from Business that Have Certain Gross Circulation with the aim to improve tax compliance. For Small and Medium Enterprises, the application of this rule is expected to facilitate taxpayers in tax reporting. This study will analyze the application of $1 \%$ final income tax from the turnover of Small and Medium Enterprises policies. What are the underlying considerations to apply special rules for income tax for Small and Medium Enterprises, simplification of rules and procedures adopted and comparison of the various provisions of the few countries that have been surveyed. The discussion will be conducted on the application of tax policy for small and medium enterprises undertaken by the countries of the Organization for Economic Cooperation and Development (OECD) which has been surveyed. Taxation policy on small and medium enterprises that will be compared among others are income tax exemption to companies with a turnover below the threshold of small businesses; reimbursement of tax forms be presumptive tax calculation; use cash basis accounting system and accounting procedures more simplified.
\end{abstract}

Keywords: Income Tax, SME, OECD.

\section{PENDAHULUAN}

\section{Latar Belakang}

Di dunia internasional Usaha Kecil dan

Menengah (UKM) memiliki partisipasi yang besar dalam perekonomian dunia, mereka mewakili 95\% dari total perusahaan di dunia menurut data dari Organization for the Cooperation and Economic Development (OECD). Organization for the Cooperation and Economic Development merupakan organisasi 
internasional yang membantu pemerintah mengatasi tantangan ekonomi, sosial dan tata kelola ekonomi global. Organisasi ini mengadakan pertemuan di mana pemerintah dapat membandingkan pengalaman penerapan kebijakan, penyelesaian atas masalah-masalah umum, mengidentifikasi praktik kebijakan yang baik dan berkoordinasi dalam penerapan kebijakan domestik dan internasional. Saat ini negara-negara anggota Organization for the Cooperation and Economic Development adalah: Australia, Austria, Belgia, Kanada, Chili, Republik Ceko, Denmark, Estonia, Finlandia, Perancis, Jerman, Yunani, Hungaria, Islandia, Irlandia, Israel, Italia, Jepang, Korea, Luksemburg, Meksiko, Belanda, Selandia Baru, Norwegia, Polandia, Portugal, Republik Slovakia, Slovenia, Spanyol, Swedia, Swiss, Turki, Inggris dan Amerika Serikat.

Berbagai upaya telah dilakukan oleh negaranegara di dunia untuk mengurangi kompleksitas kewajiban pajak penghasilan atas usaha kecil, dalam rangka untuk mendukung terciptanya kepatuhan pajak usaha kecil. Kebijakan perpajakan atas Usaha Kecil dan Menengah diantaranya adalah: pengecualian pajak penghasilan kepada perusahaan dengan omset di bawah ambang batas usaha kecil; penggantian bentuk penghitungan pajak menjadi presumptive tax; penggunaan sistem akuntansi cash basis dan prosedur akuntansi yang telah disederhanakan.

Di Indonesia sendiri pemerintah telah menerbitkan Peraturan Pemerintah Nomor 46 Tahun 2013 tentang pengenaan Pajak penghasilan atas penghasilan dari usaha yang diterima atau diperoleh wajib pajak yang memiliki peredaran bruto tertentu. Artinya wajib pajak badan atau orang pribadi yang memiliki omset tidak lebih dari 4,8 M dalam setahun akan dikenakan PPh final sebesar 1\% dari penghasilan bruto per bulan. Sekilas nampak memudahkan, namun terdapat potensi ketidakadilan karena marjin Usaha Kecil dan Menengah yang berbeda-beda. Sebuah ilustrasi, realitanya sejumlah pengusaha jasa dari berbagai sektor mungkin akan senang menyambut lahirnya kebijakan ini, dengan marjin keuntungan yang bisa dicapai 50 persen, mereka cukup mengeluarkan pajak sebesar 1 persen saja. Di sisi lain, ketika omset sudah mendekati 4,8 miliar rupiah setahun, seperti yang disyaratkan kebijakan ini, terbuka kemungkinan pelaku Usaha Kecil dan Menengah memecah entitas usahanya agar tetap dikenai pajak 1 persen, sementara di sektor lain, sejumlah pengusaha kecil bermarjin laba lebih rendah justru dirugikan, karena dampak kenaikan harga kebutuhan sehari-hari menjadi beban bagi kelangsungan usahanya.

Maksud dari pemberlakuan pungutan atas Usaha Kecil dan Menengah beromset 300 juta rupiah sampai dengan maksimal 4,8 miliar rupiah setahun merupakan wujud kemudahan yang diberikan pemerintah, karena jika pelaku Usaha Kecil dan Menengah menolak untuk mengikuti kebijakan tersebut, justru bakal dikenai pajak umum yang lebih besar dan lebih memberatkan. Hingga kini masih banyak sektor Usaha Kecil dan Menengah yang belum menjadi wajib pajak, padahal dari 
sisi pendapatan seharusnya sudah layak menjadi objek pajak. Kebijakan ini sebagai bentuk keadilan bagi seluruh masyarakat Indonesia, karena pajak bicara keadilan.

Berdasarkan survei dari Direktorat Jendral Pajak (DJP), tingkat kepatuhan masyarakat dalam melaksanakan kewajiban perpajakan masih rendah. Tercatat untuk Wajib Pajak Orang Pribadi, dari potensi sekitar 60 juta orang baru sekitar 25 juta yang telah membayar pajak, sementara Wajib Pajak Badan, Direktorat Jendral Pajak mencatat baru sekitar 520 Wajib Pajak yang membayar pajak dari sekitar 5 juta badan usaha yang memiliki laba. Sementara untuk pelaku Usaha Kecil dan Menengah masih jauh dari harapan, berdasarkan Sensus Pajak Nasional (SPN).

Dengan kondisi seperti ini, Direktorat Jendral Pajak berkeyakinan bahwa pelaku Usaha Kecil dan Menengah wajib dikenai pajak penghasilan. Birokrasi dan administrasi perpajakan juga wajib dibenahi, hal tersebut dikarenakan banyak perilaku ketidakpatuhan dalam melaksanakan kewajiban perpajakan akibat mengalami kesulitan dalam memahami administrasi perpajakan. Karena hal tersebut, maka diterapkanlah penyederhanaan aturan perpajakan dalam bentuk Pengenaan Pajak Penghasilan $(\mathrm{PPh})$ dari usaha dengan Peredaran Bruto (omset) tertentu sebagaimana diatur dalam Peraturan Pemerintah Nomor 46 Tahun 2013.

\section{Metode Penelitian}

Dalam penelitian ini, data dikumpulkan dari kuesioner yang sudah disebar ke 20 negara Organization for the Cooperation and Economic
Development (OECD) tentang sistem pajak penghasilan yang diterapkan pada usaha kecil dalam rangka menyederhanakan persyaratan kepatuhan kepatuhan pajak (tax compliance requirements), misalnya penggunaan akun akuntansi yang disederhanakan, perhitungan pajak yang disederhanakan sehingga dapat menurunkan biaya kepatuhan pajak (tax compliance costs), yaitu menurunkan jumlah waktu dan sumber daya yang dibutuhkan oleh perusahaan untuk memenuhi kewajiban perpajakan. Tergantung pada desain sistem perpajakan masing - masing negara, langkah langkah penyederhanaan mungkin tidak hanya menurunkan biaya kepatuhan pajak (tax compliance costs) saja, langkah - langkah tertentu lainnya juga dapat memberikan penghematan kepada usaha kecil atas pembayaran pajak kepada pemerintah.

Untuk analisis kebijakan perpajakan atas Usaha Kecil dan Menengah di Indonesia, informasi yang diperoleh didapatkan dari lembaga-lembaga pemerintah seperti Direktorat Jenderal Pajak dan Kementerian Keuangan Republik Indonesia. Database perusahaan kecil dan menengah yang berlokasi di Jakarta akan diidentifikasi dan ditentukan mana yang paling dapat diandalkan sebagai sampel perusahaan. Kuesioner dirancang dan disebarkan kepada sampel yang dipilih untuk mendapatkan informasi tentang pelaksanaan kebijakan perpajakan atas Usaha Kecil dan Menengah beserta efek yang dirasakan. Informasi yang diperoleh akan analisis, sehingga dapat ditarik kesimpulan yang menggambarkan hasil dari analisis tersebut. 


\section{HASIL DAN PEMBAHASAN}

Banyak kajian telah dilakukan di berbagai negara di dunia untuk mengurangi persyaratan kepatuhan usaha kecil dan menengah atas kewajiban pajak penghasilan (self-assessment), dalam rangka untuk mendukung terciptanya kepatuhan pajak pada usaha kecil dan menengah. Kajian juga dilakukan oleh negra-negara anggota Organization for the Cooperation and Economic Development. Khusus untuk negara-negara anggota Organization for the Cooperation and Economic Development, mereka telah melakukan survey terhadap anggotanya dengan mengidentifikasi berbagai macam pendekatan yang dilakukan oleh masingmasing negara anggotanya dalam menerapkan kebijakan pajak penghasilan atas usaha kecil dan menengah. Pendekatanpendekatan yang ditemukan di lapangan diantaranya adalah pengecualian perusahaan dengan omset di bawah ambang batas usaha kecil dari pengenaan pajak penghasilan yang berlaku secara umum dan menggantinya dengan "presumptive tax" dan penggunaan akuntansi berbasis kas (cash basis) serta penggunaan prosedur akuntansi yang disederhanakan.

\section{Penggantian Pajak Penghasilan Umum dengan presumptive tax.}

Memperbolehkan perusahaan dengan omset di bawah ambang batas tertentu untuk memilih sistem pemajakan pajak penghasilan khusus dapat menjadi alternatif sarana yang efektif untuk mengurangi biaya kepatuhan pajak dan biaya administrasi pajak. Di sisi lain, argumen yang cukup kuat adalah dengan menerapkan pengecualian pajak perusahaan tertentu dan menggantinya dengan sistem pemajakan yang lebih sederhana, meskipun penerapan sistem pemajakan yang lebih sederhana tersebut memerlukan biaya kepatuhan pajak dan biaya administrasi administrasi pajak, meskipun tidak signifikan. Selain meningkatkan kontribusi terhadap penerimaan pajak dan meningkatkan dukungan terhadap pemerintahan yang baik (good governance) karena bertujuan untuk meningkatkan partisipasi semua pihak termasuk pengusaha lokal yang berskala kecil kedalam sistem pajak, pemberlakuan presumptive tax dapat memudahkan transisi masuknya perusahaan ke dalam sistem pajak penghasilan umum saat ambang batas omset usaha kecil telah dilampaui dan kemudian dapat mendorong partisipasi lanjutan dalam ekonomi formal.

Selain itu, untuk meminimalisir efek ekonomi atas pajak penghasilan yang dirasakan oleh pemilik usaha, pemberian pengecualian pajak penghasilan bagi perusahaan yang beradadi bawah ambang batas omset usaha kecil juga dapat memberikan keuntungan kompetitif pada mereka atas perusahaan-perusahaan yang lebih besar. Perlakuan yang tidak netral tersebut berdampak pada menurunnya daya saing perusahaan - perusahaan yang lebih besar dan cenderung mendorong perusahaan yang dikenakan pajak penghasilan umum untuk beroperasi di sektor informal. Hal tersebut membuat para pembuat kebijakan untuk mempertimbangkan pendapat yang pro dan kontra atas penggunaan alternatif 
presumptive tax pada perusahaan yang dikecualikan dari pengenaan pajak penghasilan umum.

Pajak pengganti untuk pajak penghasilan umum biasanya disebut sebagai “presumptive taxes", dimana presumptive taxes tersebut bergantung pada suatu acuan yang pada prinsipnya bertindak sebagai pengganti (proxy) untuk penentuan dasar pajak yang diganti, dalam hal ini adalah pajak penghasilan umum. Dasar pengenaan presumptive taxes dan beban pajak yang diterapkan dapat berbeda secara signifikan dengan yang diterapkan pada pajak penghasilan umum. Perbedaan tersebut bisa sangat besar maupun sangat kecil tergantung pada jenis presumptive taxes yang diterapkan dan posisi laba wajib pajak.

Jenis presumptive taxes yang dapat digunakan sebagai pengganti pajak penghasilan umum adalah paten, pajak berbasis indikator, pajak berdasarkan omset bruto dan pajak berdasarkan omset yang disesuaikan (net). Beberapa variasi dapat ditemukan pada penerapan masing-masing jenis presumptive taxes tersebut.

\section{a) Patent}

Presumptive taxes yang paling sederhana untuk menggantikan pajak penghasilan umum adalah patent, yaitu penggunaan lump sumpada penentuan jumlah pajak perusahaan yang seragam tanpa melihat ukuran dari masing-masing perusahaan tersebut. Dalam prakteknya, patent dapat langsung menargetkan usaha kecil saat dikenakan pada jenis usaha tertentu, misalnya penata rambut dan mekanik, yang biasanya memiliki tingkatomset yang relatif rendah. Kelebihan utama dari paten adalah sederhana, sehingga dapat menekan biaya kepatuhan pajakdan administrasi menjadi rendah.

Namun, karena menggunakan nilai lump sum yang tetap, penggunaan patent dapat menyebabkan beban pajak yang relatif tinggi pada perusahaan dengan omset yang rendah dan cenderung menyebabkan distorsi pada persaingan di antara perusahaan-perusahaan dengan ukuran yang berbeda. Hal tersebut juga dapat menyebabkan pembebanan tarif pajak yang relatif tinggi terhadap kegiatan usaha, terutama ketika keuntungan yang didapatkan rendah atau mengalami kerugian. Apabila hal tersebut terjadi, dapat menimbulkan masalah cash-flow bagi perusahaan.

Tak satu pun dari negara-negara anggota Organization for the Cooperation and Economic Development yang disurvei menerapkan pajak atas usaha kecil menggunakan sistem patent sederhana.

b) Indicator-based Tax

Jenis presumptive taxes lain yang relatif sederhana adalah berdasarkan indikator ukuran perusahaan, selain berdasarkan omset atau pendapatan. Contoh indikator yang dapat digunakan adalah jumlah karyawan, luas kantor, nilai persediaan, konsumsi listrik dan variabel lain yang mungkin berkorelasi dengan jumlah pendapatan. Dasar perhitungan indicator-based tax umumnya sulit untuk dilaporkan secara keliru dibandingkan dengan pajak yang berdasarkan omset atau pendapatan, dan dapat memungkinkan 
penghematan yang signifikan atas biaya kepatuhan dan administrasi pajak.

Ciri khusus dari jenis pajak ini adalah yang membentuk dasar pemajakan adalah indikator yang digunakan. Indicator-based tax yang berdasarkan jumlah luas kantor dan/atau jumlah karyawan akan cenderung menghambat investasi pada gedung-gedung kantor dan/atau pada perekrutan karyawan tambahan. Di sisi lain, tidak seperti pajak berdasarkan pendapatan, indicator-based tax tidak memajaki pendapatan, sehingga tidak memiliki kecenderungan mempengaruhi kenaikan pendapatan yang disertai etos kerja yang meningkat. Secara umum, indicator-based tax tidak menghambat peningkatan pemanfaatan faktor-faktor produksi yang berada di luar basis pajak. Tarif pajak marjinal atas pendapatan adalah nol, sedangkan tarif pajak marjinal atas investasi gedung, persediaan atau mesin bernilai positif, mengikuti basis indikator jumlah peningkatan investasi atas gedung, persediaan atau mesin.

Efek positif lainnya dari indicator-based tax juga dapat ditemukan, tergantung pada komponen dasar yang digunakan. Sebagai contoh, di mana peningkatan jumlah konsumsi listrik menjadi dasar pemajakan, indicator-based tax akan cenderung untuk mendorong investasi dalam penggunaan teknologi yang hemat listrik.

Contoh dari penerapan indicator-based tax adalah penggunaan sistem “tax card” di negara Polandia, di mana jumlah kewajiban pajak yang ditetapkan oleh undang-undang tergantung pada bentuk dan ruang lingkup kegiatan yang dilakukan, jumlah karyawan, dan jumlah penduduk tempat di mana kegiatan usaha tersebut dilakukan. Contoh lain adalah di negara Spanyol, di mana presumptive tax diterapkan pada unincorporated businesses yang berhubungan dengan satu atau lebih dari sembilan kegiatan usaha yang didasarkan pada jumlah "modulos", yaitu parameter tertentu, termasuk jumlah karyawan, konsumsi daya listrik, jumlah meja untuk layanan restoran.

c) Turnover Tax

Bentuk umum dari presumptive tax adalah turnover tax, yaitu pajak yang dikenakan atas pendapatan kotor. Tidak seperti patent dan indicator-based tax, turnover tax bervariasi berdasarkan ukuran perusahaan yang dilihat dari besarnya omset, sehingga dapat menghindari distorsi kompetitif yang mungkin terjadi pada penerapan pajak atas laba. Namun turnover tax menyebabkan pengenaan tarif pajak efektif yang lebih rendah pada perusahaan yang menghasilkan keuntungan yang lebih besar daripada yang lain. Sebagai contoh, di mana dua perusahaan memiliki omset 100 juta, perusahaan A menghasilkan keuntungan 20 juta, sedangkan perusahaan B menghasilkan keuntungan hanya 10 juta, turnover tax sebesar 5 persen dari omset menyebabkan 25 persen tarif pajak efektif atas keuntungan perusahaan A, sedangkan pada perusahaan $\mathrm{B}$, turnover tax sebesar 5 persen dari omset menyebabkan 50 persen tarif pajak efektif atas keuntungan perusahaan B. Dengan demikian, turnover tax selain mengakibatkan beban pajak yang lebih tinggi pada perusahaan yang kurang efisien, juga akan cenderung untuk mencegah alokasi 
modal atas kegiatan usahadengan margin keuntungan yang sedikit.

Turnover tax dapat diterapkan pada perusahaan dengan pendapatan kotor di bawah ambang batas usaha kecil dengan menggunakan tarif tunggal atau tarif bertingkat dan dapat diterapkan secara seragam atau bervariasi berdasarkan jenis sektor usaha. Meskipun dapat meningkatkan kompleksitas, salah satu keuntungan potensial dari penggunaan struktur tarif bertingkat yaitu pengenaan tarif yang rendah pada perusahaan dengan omset yang rendah, sehingga mendorong peningkatan kepatuhan pajak pada perusahaan yang baru berdiri. Biaya kepatuhan pajak yang rendah dan tarif pajak yang rendah yang dikenakan terhadap omset yang kecil di tahun-tahun awal berdirinya perusahaan merupakan kombinasi yang efektif untuk mendorong partisipasi perusahaan-perusahaan yang baru berdiri di dalam sistem pajak. Setelah berada di dalam sistem perpajakan, perusahaan dapat memutuskan untuk tetap beroperasi di sektor formal, keputusan ini diambil jika tarif pajak paling tinggi diatur untuk menghindari penyesuaian atas besarnya beban pajak yang ditanggung ketika ambang batas usaha kecil telah dilampaui.

Mengingat bahwa turnover tax cenderung memberlakukan tarif pajak yang lebih tinggi pada usaha dengan margin keuntungan yang rendah, beberapa negara menurunkan tarif pajak atas usaha di sektor-sektor di mana tingkat keuntungan rata-ratanya relatif rendah. Dengan diferensiasi sektor, kompleksitas dapat terjadi dengan menerapkan tarif tunggal daripada tarif bertingkat, dengan tarif yang ditetapkan lebih rendah pada sektor-sektor di mana margin keuntungan rata-rata yang lebih rendah dan sebaliknya tarif yang ditetapkan lebih tinggi pada sektor-sektor di mana margin keuntungan rata-rata yang lebih tinggi. Pada sistem tarif tunggal, efek dari struktur tarif yang berjenjang, yaitu mendorong kepatuhan pajak pada perusahaan-perusahaan yang baru berdiri dapat diganti dengan menerapkan beberapa biaya pengurang atas omset yang menjadi dasar pajak.

Sebagai tambahan, dalam membuat proxy pendapatan yang lebih baik dari patent dan indicator-based taxes, penggunaan turnover tax akan menghindari distorsi kompetitif akibat pajak atas laba. Turnover tax juga memfasilitasi penyesuaian perusahaan saat masuk ke dalam sistem pajak penghasilan umumdengan permintaan pemeliharaan atas rekening kas dalam mengukur omset. Seperti presumptive taxes lainnya, penggunaan sistem turnover tax dapat mengurangi biaya kepatuhan pajak dan mungkin juga mengurangi beberapa kewajiban pajak perusahaan, sehingga dapat mendorong terciptanya kepatuhan pajak pada usaha kecil. Meskipun secara umum turnover tax dikatakan dapat mengurangi kewajiban pajak atas usaha kecil dibandingkan dengan pajak penghasilan umum, akan tetapi hal tersebut tergantung pada aturan khusus yang diterapkan pada kedua jenis pajak tersebut dan bergantung juga pada tingkat omset dan laba/rugi pada perusahaan, termasuk tingkat fleksibilitas atas 
kerugian usaha pada ketentuan pajak penghasilan umum.

Di negara Meksiko, usaha kecil (Repecos) dengan omset di bawah \$91.200 pada tahun pajak sebelumnya, dikenakan pajak pada sebesar 2 persen dari pendapatan kotor. Untuk wajib pajak yang memutuskan untuk memilih menggunakan pajak penghasilan umum, keputusan tersebut tidak dapat diubah. Unincorporated businesses di negara Polandia memiliki pilihan untuk dikenakan pajak penghasilan umum atau dikenakan pajak berdasarkan presumptive tax atas peredaran bruto (tidak ada pengurangan untuk biaya) dengan tarif yang bervariasi berdasarkan jenis kegiatan usaha. Seperti di negara-negara anggota Organization for the Cooperation and Economic Development lainnya, pendapatan individu dari unincorporated business dikenakan pajak penghasilan orang pribadi. Di Polandia, unincorporated business non-pertanian dapat memilih dikenakan pajak 19 persen, sama dengan pajak penghasilan badan yang diterapkan pada incorporated businesses, atau dikenakan pajak berdasarkan turnover-based taxation (tarif pajak "lump-sum" dikenakan terhadap pendapatan yang dilaporkan).

Unincorporated businesses di negara Spanyol yang melakukan kegiatan usaha pertanian diperbolehkan untuk memilih dikenakan pajak menggunakan sistem berbasis omset dengan syarat omsetnya tidak melebihi \$ 389.970. Spanyol menerapkan indicators-based tax untuk kegiatan usaha lain (non-pertanian) yang berada di bawah ambang batas usaha kecil.

d) Net (adjusted) Turnover Tax
Mirip dalam bentuk dan efeknya dengan pajak penghasilan umum adalah presumptive taxes yang menggunakan adjusted turnover tax base (pendapatan kotor). Mengingat tujuan pajak pengganti adalah untuk mengendalikan biaya kepatuhan pajak, penyesuaian biaya cenderung menjadi hal yang dapat dengan mudah untuk diukur. Bukan menyusutkan biaya modal misalnya, perusahaan diperbolehkan untuk membebankan langsung biaya modal secarapenuh. Adjusted (net) turnover taxes mungkin sekilas terlihat mirip dengan cash-flow taxes, karena memperbolehkan pembebanan langsung biaya modal, mengkoreksi pembebanan atas beban bunga, dan mengecualikan pendapatan bunga dari dasar pengenaan pajak.

Adjusted turnover taxes berbeda karena memungkinkan perhitungan yang disederhanakan untuk menghitung biaya usaha tertentu, misalnya seperti dalam prakteknya di negara Austria yang memberikan pengurangan standar sebesar 12 persen dari omset. Bukan mengharuskan perusahaan untuk menghitung biaya persediaan, pengurang “lump sum” sederhana dapat digunakan sebagai input costs, yang ditentukan dari persentase atas omset. Pembuat kebijakan mengacu pada pengurang yang disederhanakan untuk input costs yang ditentukan dari persentase atas omset yang disebut pengurang “lump sum”, meskipun pengurang tersebut tidak tetap jumlahnya. Pengurang terdiri dari upah dan biaya lainnya yang mungkin ada serta pajak.

Negara Austria menerapkan contoh dari jenis presumptive tax tersebut yang diterapkan pada 
unincorporated businesses saja, di mana basis pajak diukur dari omset dikurangi upah, cost of goods dan pajak terkait termasuk PPN masukan, dikurangi deductible expenses yang dihitung sebesar 12 persen dari omset dengan nilai maksimum \$ 34.317. Pengurang “lump sum" yang dimodifikasi berlaku untuk restoran, hotel, pengecer makanan dan beberapa kegiatan usaha lainnya, contohnya untuk profesional independen, biaya yang dapat dikurangkan dihitung sebesar 6 persen dari omset. Penyederhanaan berlaku untuk usaha di bawah ambang batas omset yang bervariasi sesuai dengan sektor usaha, dengan ambang batas umum sebesar \$288.578. Untuk restoran dan hotel, ambang batas omset yang menggunakan presumptive tax adalah di bawah \$331.475. Untuk toko obat dan pengecer makanan, ambang batas omset masing-masing adalah sebesar \$ 519.960 dan \$ 779.940 yang dihitung pada 2 tahun sebelumnya. Jika perusahaan memutuskan untuk memilih tidak memakai perhitungan ini, keputusan tersebut mengikat selama 5 tahun.

\section{Akuntansi Yang Disederhanakan Untuk Perusahaan Kecil}

Sistem pajak penghasilan di sebagian besar negara-negara anggota Organization for the Cooperation and Economic Development berbasis accrual. Dalam akuntansi kas, pajak penghasilan yang dihitung atas pendapatan baru dibayar ketika kas diterima, dan input costs diklaim pada saat kas dibayarkan. Sistem akuntansi kas ditargetkan pada Usaha Kecil dan Menengah, penentuan laba kena pajak berdasarkan pendapatan yang benar-benar telah diterima dan biaya yang telah dibayar, termasuk pembebanan langsung atas pembelian barang modal, dapat secara signifikan mengurangi biaya kepatuhan, tergantung pada dokumentasi pendukung tambahan yang wajib pajak harus sediakan. Langkah-langkah penyederhanaan lain termasuk penyederhanaan persyaratan pembukuan.

Di negara Austria, unincorporated businesses dengan omset di bawah \$ 519.960 tidak diharuskan untuk membuat laporan keuangan penuh, hanya pendapatan dan beban yang harus dilaporkan.

Usaha kecil di negara Belgia dengan omset di bawah \$ 649.950 (tidak termasuk PPN) menggunakan aturan akuntansi sederhana yang menetapkan bahwa semua transaksi harus sepenuhnya tercatat dalam buku kas, buku pembelian dan buku penjualan. Selain itu, daftar inventaris harus dibuat setidaknya setahun sekali yang menunjukkan semua kredit, hutang dan sumber daya yang digunakan dalam usaha. Aturan akuntansi sederhana yang mngharuskan akuntansi double-entry dan inventarisasi tahunan juga berlaku untuk Usaha Kecil dan Menengah di Belgia dengan syarat: rata-rata jumlah karyawan tidak lebih dari 50 orang sepanjang tahun; omset tahunan (tidak termasuk PPN) tidak lebih besar dari \$ 9.489.270; dan total aset tidak lebih dari $\$ 4.744 .635$.

Untuk perusahaan di bawah batas omset atau keuntungan tertentu di negara Jerman, akuntansi kas dapat digunakan untuk keperluan pajak, dalam pembuatan laporan 
keuangan penuh (laporan rugi laba dan neraca). Ambang batas omset dalam menentukan kewajiban untuk menjaga pembukuan dan catatan untuk tujuan pajak baru-baru ini naik lagi dari € 350,000 menjadi $€ 500.000$

Di negara Yunani, aturan akuntansi dan prosedur yang disederhanakan berlaku untuk usaha dengan batas omset tahunan di bawah $€$ 300.000 untuk perusahaan perdagangan dan $€$ 150.000 untuk perusahaan jasa.

Di negara Spanyol, investasi pada aset yang bernilai rendah, yang didefinisikan sebagai aset dengan nilai di bawah $\$ 782$, dapat dibebankan sebagai biaya (bebas disusutkan), sampai keseluruhan dalam periode pajak pembebanan langsung sebesar $\$ 15.630$.

Usaha kecil, usaha perseorangan di negara Norwegia dengan aset hingga \$3.1 juta atau memiliki karyawan tidak lebih dari 20 orang atau kemitraan umum dengan omset tidak lebih besar dari \$ 785.150 dan memiliki karyawan tidak lebih dari 4 orang dikecualikan dari kewajiban membuat laporan tahunan. Namun, usaha dalam grup tersebut harus membuat laporan tahunan untuk keperluan pajak penghasilan, untuk menentukan penghasilan kena pajak dan aset yang dimiliki.

Di negara Polandia, unincorporated businesses dengan omset di bawah $\$ 1$ juta hanya dikenai kewajiban membuat pembukuan pajak atas pendapatan dan beban, sedangkan wajib pajak badan, dan unincorporated taxpayers dengan omset lebih dari $\$ 1$ juta harus membuat laporan keuangan standar. Australia menerapkan aturan penyusutan yang disederhanakan untuk Usaha Kecil dan Menengah. Secara khusus, melalui Simplified Tax System (STS) usaha kecil dengan omset tidak lebih besar dari \$ 1.6 juta diperbolehkan untuk menyatukan aset yang dapat disusutkan untuk tujuan depresiasi, dan untuk mengklaim pengurangan langsung atas asetdengan biaya tertentu (aset yang biayanya kurang dari \$ 784). Pembayar pajak melalui sistem Simplified Tax System juga memiliki akses ke aturan sederhana perdagangan saham. Aset dengan masa manfaat kurang dari 25 tahun dialokasikan pada general small business pool yang disusutkan sebesar 30 persen, sementara aset yang memiliki masa manfaat 25 tahun atau lebih dialokasikan pada long life small business pool yang disusutkan sebesar 5 persen. Prosedur akuntansi yang disederhanakan diterapkan di negara Spanyol untuk unincorporated dan incorporated businesses dengan omset di bawah $\$ 2.599 .800$, total aset yang dimiliki tidak melebihi $\$ 1.299 .900$, dan rata-rata sepanjang tahun memiliki karyawan tidak lebih dari 10 orang.

Di negara Swedia, yang berpedoman pada hubungan yang kuat antara dasar pengenaan pajak dan rekening keuangan, aturan akuntansi yang disederhanakan hanya berlaku untuk pedagang individu dengan omset di bawah SEK 3 juta.

Di negara Inggris, unincorporated businesses dengan keuntungan di bawah \$ 29.389 diperbolehkan untuk menggunakan laporan self-assessment yang disederhanakan. Sama halnya untuk laporan perpajakan perusahaan yang disederhanakan dapat digunakan oleh 
perusahaan dengan pajak yang disederhanakan.

Di negara Amerika Serikat, metode akuntansi kas, bukan akuntansi akrual, dapat digunakan oleh perusahaan dengan rata-rata omset (penerimaan kotor tahunan) selama 3 tahun terakhir kurang dari \$ 1 juta dan oleh perusahaan dengan omset rata-rata lebih dari $\$ 1$ juta tetapi kurang dari \$ 10 juta yang tidak bergerak dalam bidang perdagangan, manufaktur, pertambangan, atau industri informasi.
Selain itu, perusahaan denganrata-rata omsettidak lebih dari \$ 10 juta dikecualikan dari kewajiban kapitalisasi umum untuk mengkapitalisasi biaya langsung dan bagian dari biaya tidak langsung dari kegiatan produksi atau penjualan kembali.

\section{Kebijakan Pajak Penghasilan Atas Usaha} Kecil Dan Menengah Di Indonesia

Pada bulan Juli tahun 2013, pemerintah menerbitkan Peraturan Pemerintah No.46

Tabel 1.Data Perkembangan Usaha Mikro, Kecil, Menengah (UMKM) dan Usaha Besar (UB) Tahun 2010-2012

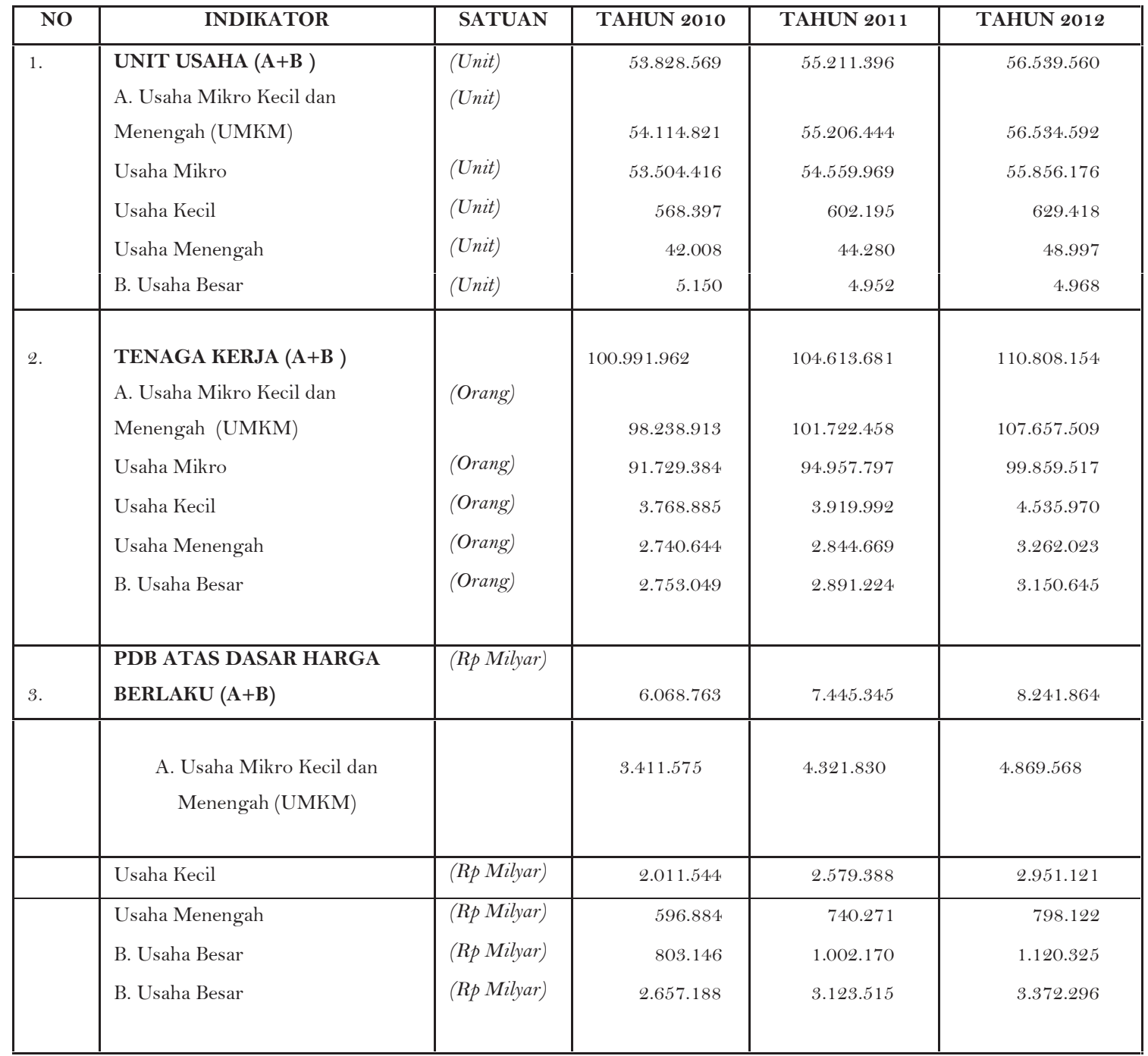

Sumber: Kementerian Koperasi dan UKM (diolah) 
Tahun 2013 tentang Pengenaan Pajak Penghasilan atas Penghasilan dari Usaha yang Diterima atau Diperoleh Wajib Pajak yang Memiliki Peredaran Bruto Tertentu.

Artinya wajib pajak badan atau orang pribadi yang memiliki omzet tidak lebih dari 4,8 M dalam setahun akan dikenakan $\mathrm{PPh}$ final sebesar $1 \%$ dari penghasilan bruto per bulan.

Sasaran utama dari pengenaan Peraturan Pemerintah No.46 tahun 2013 ini adalah para pelaku Usaha Mikro, Kecil, dan Menengah (UMKM).

Pelaku Usaha Mikro, Kecil, dan Menengah dianggap sebagai sumber yang potensial dalam hal penerimaan kas negara sehingga pemerintah khususnya Direktorat Jenderal Pajak ingin memfasilitasi para pelaku Usaha Mikro, Kecil, dan Menengah di Indonesia dengan cara memberikan kemudahan administrasi dalam pemenuhan kewajiban perpajakan, seperti yang ditunjukkan dalam tabel pertumbuhan jumlah Usaha Mikro, Kecil, dan Menengah yang ada di Indonesia. (Tabel 1)

Dari Tabel 1 dapat kita lihat bahwa pada tahun 2012 jumlah Usaha Mikro, Kecil, dan Menengah di Indonesia mencapai 56,5 juta unit yang terdiri dari berbagai industri. Sekitar $90 \%$ pasar Indonesia kini dikuasai oleh Usaha Mikro, Kecil, dan Menengahdan $57 \%$ PDB (Produk Domestik Bruto) merupakan kontribusi dari Usaha Mikro, Kecil, dan Menengah. Dengan jumlah wajib pajak dari sektor Usaha Mikro, Kecil, dan Menengah yang sangat besar ini peran Peraturan Pemerintah No.46 tahun 2013 diharapkan dapat berjalan efektif guna memperbesar pendapatan negara dari Pajak Penghasilan sektor Usaha Mikro, Kecil, dan Menengah.

Selain itu dengan diberikannya kemudahan administrasi pada Peraturan Pemerintah No.46 tahun 2013, pemerintah bertujuan untuk memberikan edukasi kepada Wajib Pajak sektor Usaha Mikro, Kecil, dan Menengah agar semakin tertib dalam memenuhi kewajiban perpajakan. Banyak pro dan kontra yang timbul terkait dengan penerapan Peraturan Pemerintah No.46 tahun 2013 ini, peraturan ini merujuk pada Pajak Penghasilan final pasal 4 ayat 2 dimana mekanisme pemajakannya telah dianggap selesai pada saat dilakukan pemotongan, pemungutan dan atau penyetoran sendiri oleh Wajib Pajak yang bersangkutan.

Apabila peraturan ini dikenakan pada Wajib pajak badan maka kerugian pada tahun sebelumnya tidak dapat dikompensasikan. Nilai $1 \%$ dari omset per bulan juga dianggap terlalu besar untuk ukuran wajib pajak yang baru merintis usahanya apabila dibandingkan dengan tarif progresif yang sebelumnya diberlakukan.

Pelaku usaha - wajib pajak mengeluh karena pemberlakuannya sangat cepat sehingga membuat kelabakan karena belum siap dengan sistem tersebut. Tubagus Fiki Chikara Satari, pengusaha Distro asal Bandung menyatakan bisnisnya pasti terdampak jika dikenai $\mathrm{PPh}$ $1 \%$. Dia ingin pemerintah memberi insentif nyata agar Usaha Mikro, Kecil, dan Menengah semakin maju. Jangan hanya pajak yang dikejar-kejar. Salah satu bantuan nyata dari pemerintah, menurutnya, melindungi 
pengusaha kecil dari serbuan produk impor. "Selama ini kami berjuang sendiri menghadapi persaingan dengan produk asing murah yang makin banyak beredar di dalam negeri," tandas Fikri yang usaha di bidang fesyen.

Beberapa pokok-pokok penting yang diatur dalam Peraturan Pemerintah No.46 tahun 2013yang diberlakukan efektif mulai 1 Juli 2013 tersebut adalah sebagai berikut:

1. Bagi Wajib Pajak orang pribadi atau Wajib

Pajak badan tidak termasuk bentuk usaha tetap yang menerima penghasilan dari usaha dengan peredaran bruto tidak melebihi Rp.4.8 milyar dalam 1 (satu) Tahun Pajak, dikenakan Pajak Penghasilan yang bersifat final dengan tarif $1 \%$.

2. Dasar pengenaan pajak yang digunakan untuk menghitung Pajak Penghasilan yang bersifat final adalah jumlah peredaran bruto setiap bulan.

3. Dikecualikan dari pengenaan $\mathrm{PPh}$ Final berdasarkan ketentuan ini adalah penghasilan dari jasa sehubungan dengan pekerjaan bebas yang diperoleh:

a. tenaga ahli yang melakukan pekerjaan bebas, yang terdiri dari pengacara, akuntan, arsitek, dokter, konsultan, notaris, penilai, dan aktuaris;

b. pemain musik, pembawa acara, penyanyi, pelawak, bintang film, bintang sinetron, bintang iklan, sutradara, kru film, foto model, peragawan/peragawati, pemain drama, dan penari;

c. olahragawan;

d. penasihat, pengajar, pelatih, penceramah, penyuluh, dan moderator;

e. pengarang, peneliti, dan penerjemah; f. agen iklan;

g. pengawas atau pengelola proyek

h. perantara

\section{Tidak termasuk Wajib Pajak}

Tidak termasuk dalam pengertian Wajib Pajak yang dikenakan dengan PP ini adalah:

a. Wajib Pajak orang pribadi yang melakukan kegiatan usaha perdagangan dan / atau jasa yang dalam usahanya:

i. menggunakan sarana atau prasarana yang dapat dibongkar pasang, baik yang menetap maupun tidak menetap; dan

ii. menggunakan sebagian atau seluruh tempat untuk kepentingan umum yang tidak diperuntukkan bagi tempat usaha atau berjualan.

Contoh: pedagang makanan keliling, pedagang asongan, warung tenda di trotoar dan sejenisnya.

b. Wajib Pajak badan:

i. yang belum beroperasi secara komersial; atau

ii. yang dalam jangka waktu 1 (satu) tahun setelah beroperasi seara komersial memperoleh peredaran bruto melebihi Rp. 4,8 milyar.

5. Peraturan Pemerintah No.46 tahun 2013 ini tidak berlaku atas penghasilan dari usaha yang selama ini telah dikenai Pajak Penghasilan yang bersifat final berdasarkan ketentuan perpajakan yang berlaku.

6. Ketentuan lebih lanjut mengenai penghitungan, penyetoran Pajak Penghasilan atas penghasilan dari usaha yang diterima 
atau diperoleh Wajib Pajak yang memiiki peredaran bruto tertentu dan kriteria beroperasi secara komersial diatur dengan atau berdasarkan Peraturan Menteri Keuangan (PMK).

Meski tidak secara eksplisit dinyatakan dalam PP 46 tahun 2013, sulit dipungkiri bahwa yang menjadi target pemajakan dalam ketentuan perpajakan baru ini adalah Usaha Mikro Kecil dan Menengah (UMKM). Hal ini terlihat dari batasan peredaran usaha Rp.4,8 milyar dalam Peraturan Pemerintah No.46 tahun 2013tersebut yang masih dalam lingkup pengertian Usaha Mikro Kecil dan Menengah menurut Undang-undang No. 20 Tahun 2008 tentang Usaha Mikro, Kecil dan Menengah, yakni usaha yang dilakukan orang perorangan atau badan usaha dengan peredaran maksimum Rp.50 milyar dalam setahun.

Terkait dengan Usaha Mikro Kecil dan Menengah, sebelumnya sudah ada ketentuan perpajakan yang mengatur tarif khusus Pajak Penghasilan untuk Usaha Mikro Kecil dan Menengah tetapi hanya berlaku untuk yang berbentuk badan usaha. Dalam Undang Undang No.36 Tahun 2008 pasal 31 E dinyatakan bahwa Wajib Pajak badan dalam negeri dengan peredaran bruto sampai dengan Rp.50 milyar mendapat fasilitas berupa pengurangan tarif sebesar 50\% dari tarif umum sebagaimana diatur dalam pasal 17 ayat (2) Undang Undang Pajak Penghasilan yang dikenakan atas Penghasilan Kena Pajak dari bagian peredaran bruto sampai dengan Rp.4,8 milyar. Dengan tarif Pajak Penghasilan Badan yang berlaku saat ini yaitu 25\%, maka bagi Wajib Pajak badan dalam negeri yang memenuhi syarat, tarif efektifnya menjadi $12,5 \%$ atas penghasilan sampai dengan Rp.4,8 milyar. Pengenaan Pajak Penghasilandalam hal ini dilakukan terhadap penghasilan kena pajak yang dihitung dari perhitungan laba-rugi akuntansi (pembukuan) setelah dilakukan koreksi fiskal karena berdasarkan pasal 28 ayat (1) Undangundang Nomor 28 Tahun 2007, Wajib Pajak badan diwajibkan menyelenggarakan pembukuan.

Rencana menjadikan Usaha Mikro Kecil dan Menengahsebagai fokus atau target pemajakan telah terdengar sejak petengahan tahun 2011. Saat itu sumber data menunjukkan bahwa Usaha Mikro Kecil dan Menengah menyumbang $61 \%$ dari Produk Domestik Bruto tetapi kontribusinya terhadap total penerimaan pajak hanya $5 \%$. Oleh karena itu kuat dugaan bahwa terbitnya Peraturan Pemerintah No.46 tahun 2013 adalah karena potensi penerimaan pajak dari sektor Usaha Mikro Kecil dan Menengahbelum tergali secara maksimal. Hal ini sedikit berbeda dengan penjelasan Menteri Keuangan barubaru ini yang dikutip beberapa harian nasional dan media elektronik yang mengatakan bahwa keputusan Pemerintah mengenakan tarif $1 \%$ terhadap Usaha Mikro Kecil dan Menengah bukanlah alasan penerimaan negara tetapi bermaksud meningkatkan status Usaha Mikro Kecil dan Menengahmenjadi sektor formal sehingga lebih mudah memperoleh akses keuangan, permodalan maupun kredit perbankan. Penjelasan Menteri Keuangan ini patut dipertanyakan karena maksud tersebut 
tidak tercemin dalam konsiderans (pertimbangan) terbitnya Peraturan

Pemerintah No.46 tahun 2013.

\section{PENUTUP}

\section{Simpulan}

Beberapa negara anggota Organization for the Cooperation and Economic Development menerapkan sistem presumptive, yaitu Austria, Belgia, Republik Ceko, Yunani, Italia, Jepang, Meksiko, Polandia dan Spanyol. Jawaban kuesioner tentang motivasi dalam menggunakan sistem presumptive terbagi ke dalam dua kelompok. Kelompok pertama yang terdiri dari Austria, Belgia, Republik Ceko, Polandia dan Meksiko menyatakan bahwa motivasi dalam menggunakan sistem presumptive adalah pembukuan yang sederhana dan pengolahan laporan pajak yang sederhana. Kelompok kedua yang terdiri dari Yunani, Italia, Jepang dan Spanyol menyatakan bahwa motivasi dalam menggunakan sistem presumptive adalah peningkatan kepatuhan pajak, pengurangan penghindaran pajak dan pemajakan yang lebih adil.

Motivasi yang berbeda tersebut cenderung tercermin dari sejauh mana perusahaan dapat memilih tidak menggunakan sistem presumptive. Sementara Austria, Belgia, Polandia dan Meksiko memberikan kesempatan pembayar pajak untuk memilih tidak menggunakan sistem presumptive, hal ini tidak terjadi di Yunani, Italia dan Jepang. Kriteria yang memenuhi syarat untuk menggunakan sistem presumptive juga berbeda. Dalam kasus Austria, Belgia,
Polandia dan Meksiko, pembayar pajak usaha kecil menjadi target, sementara di Italia misalnya, usaha dengan keuntungan hingga US \$ 9,7 juta dapat didorong menggunakan sistem presumptive.

Pembedaan aturan untuk perusahaan besar dan Usaha Kecil dan Menengah juga berlaku dalam akuntansi. Akuntansi pajak menjadi salah satu alasan utama mengapa usaha kecil menanggung biaya kepatuhan yang lebih tinggi dibandingkan dengan perusahaan besar.

Di Indonesia, penerapan Pajak Penghasilan Final 1\% terhadap Usaha Mikro Kecil dan Menengah yang mempunyai peredaran bruto tidak lebih dari Rp.4,8 milyar setahun adalah tepat jika hanya dilihat dari sisi kemudahan dalam penghitungan pajak bagi kelompok perorangan dan badan usaha yang selama ini kesulitan menyelenggarakan pembukuan. Namun bagi Usaha Mikro Kecil dan Menengah perorangan atau badan usaha yang selama ini telah menyelenggarakan pembukuan dengan tertib dan menghitung PPh dari penghasilan kena pajak yang senyatanya dari hasil pembukuan setelah dilakukan koreksi fiskal, ketentuan ini menjadi suatu kemunduran bagi mereka. Betapa tidak, untuk kelompok ini, konsep self - assessment yang memberi kepercayaan kepada Wajib Pajak untuk menghitung, memperhitungkan, menyetor dan melaporkan sendiri kewajiban pajaknya jelas menjadi tidak bermakna.

Kebijakan pengenaan Pajak Penghasilan Final terhadap Usaha Mikro Kecil dan Menengah mundur dan tidak selaras dengan tujuan utama dari sistem self - assesment yaitu 
kepatuhan membayar pajak secara sukarela (voluntary compliance).

Semangat pemerintah dalam mengejar target penerimaan negara lebih dominan terlihat dalam penerbitan Peraturan Pemerintah No.46 tahun 2013.

Jadi, lebih dari sekedar memberi kemudahan kepada Usaha Mikro Kecil dan Menengah dalam melakukan penghitungan, penyetoran, dan pelaporan Pajak Penghasilan yang terutang, dan tidak pula tampak jelas dalam rangka mendorong Usaha Mikro Kecil dan Menengah mudah dalam akses ke sektor keuangan, permodalan dan kredit perbankan.

\section{Saran}

Untuk memberikan gambaran yang lebih luas tentang kebijakan pajak dan pengaturan administrasi, survei yang serupa sebaiknya dilakukan bekerja sama dengan International Monetary Fund (IMF) sehingga responden menjadi luas ke negara-negara non anggota Organization for the Cooperation and Economic Development. World Bank juga diharapkan dapat berpartisipasi dalam survei tersebut. International Monetary Fund, Organization for the Cooperation and Economic Development dan World Bank selanjutnya dapat berkoordinasi dalam upaya mereka untuk menggelar International Tax Dialogue (ITD) yang diadakan untuk memfasilitasi diskusi tentang masalah pajak antara pejabat pajak nasional dengan organisasi internasional.

\section{DAFTAR PUSTAKA}

Chen, D., F. C. Lee and J. Mintz, 2002, Taxation, SMEs and Entrepreneuship, STI Working Paper 2002/9 , Paris: OECD.

Commission Of The European Communities, 2003, The Definition of Micro, Small and MediumSized Enterprises, Commission Recommendation of 06/05/2003, Brussels: Commission Of The European Communities.

Coyne, E. J., 1995, Proposed Analytical Model for FDI Attraction Into Developing Countries, Essays in International Business 1, The International Business Center, College of Professional Studies, Washington, D.C: University of the District of Columbia.

Hendricks, K., R. Amit and D. Whistler, 1997, Business Tax-ation of Small and Medium-sized Enterprises in Canada, Ottawa: Department of Finance Working Paper 97-11, Government of Canada.

International Finance Corporation, 2010, Micro, Small and Medium Enterprise Country Indicators (MSME-CI), Washington, D.C: International Finance Corporation.

OECD Ministers and Government Representatives, 3-5 June 2004, OECD Istanbul Ministerial Declaration on Fostering the Growth of Innovative and Internationally Competitive SMEs, Istanbul:OECD. 
OECD Working Party on SMEs and Entrepreneurship, 21 March 2007, Survey On The Taxation Of Small And Medium-Sized Enterprises, Paris: OECD.

Syahdan, Saifhul Anuar dan Rani, Asfida Parama, 2014, Dimensi Keadilan Atas Pemberlakuan PP No. 46 Tahun 2013 Dan Peningkatan Kepatuhan Wajib Pajak, Banjarmasin: Prosiding Simposium Nasional Perpajakan 4.

Tambunan, Ruston, 2013, Ketentuan Terbaru Pajak Penghasilan Atas UMKM: Sederhana Tapi Tidak Adil, Jakarta: Observation and Research of Taxation.

World Bank, 2006, Expanding Access to Finance: Good Practices and Policies for Micro, Small, and Medium Enterprises, Washington, D.C : The World Bank Group. 